\title{
Changes in Growth, Photosynthetic Pigments, Cell Viability, Lipid Peroxidation and Antioxidant Defense System in Two Varieties of Chickpea (Cicer arietinum L.) Subjected to Salinity Stress
}

\author{
Zeenat Mushtaq $^{1}$, Shahla Faizan ${ }^{1}$, Basit Gulzar $^{2}$, Humira Mushtaq $^{3}$, Sayyada Bushra ${ }^{1}$, Alisha Hussain ${ }^{1}$ \\ and Khalid Rehman Hakeem ${ }^{4, *}$ \\ ${ }^{1}$ Environmental Physiology Laboratory, Department of Botany, Aligarh Muslim University, Aligarh, 202002, India \\ ${ }^{2}$ Cellular Differentiation and Molecular Genetics Section, Department of Botany, Jamia Hamdard, New Delhi, 110062, India \\ ${ }^{3}$ Research and Training Centre for Pollinators, Pollinizers and Pollination Management Section, Division of Entomology, SKUAST \\ Kashmir, Srinagar, 190025, India \\ ${ }^{4}$ Department of Biological Sciences, Faculty of Science, King Abdulaziz University, Jeddah, 21589, Saudi Arabia \\ ${ }^{*}$ Corresponding Author: Khalid Rehman Hakeem. Email: kur.hakeem@gmail.com; khakim@kau.edu.sa
}

Received: 19 February 2021 Accepted: 25 May 2021

\begin{abstract}
Salinity is one of the most severe abiotic stresses for crop production. The present study investigates the salinityinduced modulation in growth indicators, morphology and movement of stomata, photosynthetic pigments, activity of carbonic anhydrase as well as nitrate reductase, and antioxidant systems in two varieties of chickpea (Pusa-BG5023, and Pusa-BGD72). On $20^{\text {th }}$ day of sowing, plants were treated with varying levels of $\mathrm{NaCl}(0,50$, 100,150 and $200 \mathrm{mM}$ ) followed by sampling on 45 days of sowing. Recorded observations on both the varieties reveal that salt stress leads to a significant decline in growth, dry biomass, leaf area, photosynthetic pigments, protein content, stomatal behavior, cell viability, activity of nitrate reductase and carbonic anhydrase with the rise in the concentration of salt. However, quantitatively these changes were less in Pusa-BG5023 as compared to Pusa-BGD72. Furthermore, salinity-induced oxidative stress enhanced malondialdehyde content, superoxide radicals, foliar proline content, and the enzymatic activities of superoxide dismutase, catalase, and peroxidase. The variety Pusa-BGD72 was found more sensitive than Pusa-BG5023 to salt stress. Out of different graded concentrations $(50,100,150$ and $200 \mathrm{mM}$ ) of sodium chloride, $50 \mathrm{mM}$ was least toxic, and $200 \mathrm{mM}$ was most damaging. The differential behavior of these two varieties measured in terms of stomatal behavior, cell viability, photosynthetic pigments, and antioxidant defense system can be used as prospective indicators for selection of chickpea plants for salt tolerance and sensitivity.
\end{abstract}

\section{KEYWORDS}

Salt stress; ion homeostasis; antioxidant defense; cell viability; chickpea

$\begin{array}{ll}\text { Abbreviations } \\ \text { ROS: } & \text { reactive oxygen species, } \\ \text { ANOVA: } & \text { analysis of variance, } \\ \text { TCA: } & \text { trichloroacetic acid, }\end{array}$

This work is licensed under a Creative Commons Attribution 4.0 International License, which permits unrestricted use, distribution, and reproduction in any medium, provided the original work is properly cited. 


$\begin{array}{ll}\text { OD: } & \text { optical density, } \\ \text { MDA: } & \text { malondialdehyde, } \\ \text { thiobarbituric acid, } \\ \text { TBA: } & \text { thiobarbituric-acid-reacting substance, } \\ \text { PBA: } & \text { peroxidase, } \\ \text { SOD: } & \text { Superoxide dismutase, } \\ \text { NBT: } & \text { nitro blue tetrazolium, } \\ \text { GR: } & \text { glutathione reductase, } \\ \text { CAT: } & \text { catalase, } \\ \text { APX: } & \text { ascorbate peroxidase, } \\ \text { FAO: } & \text { Food and Agriculture Organization. }\end{array}$

\section{Introduction}

Plants have to face many adverse and harsh biotic and abiotic stresses due to their sedentary habit. Salt stress is one of the most important abiotic stresses and unavoidable restrain of crop productivity on earth mainly in those regions that receive less annual precipitation and contain high concentration of salt in soil [1-3]. Natural factors like weathering of rocks, volcanic eruptions and cyclones in seas as well as anthropogenic factors like excessive use of chemical fertilizers, industrialization, irrigation of fields with salt contaminated water, deforestation, overgrazing and population explosion are the factors responsible for soil salinization [4-6] Excess of $\mathrm{NaCl}$ makes the soil sodic due to the presence of excess $\mathrm{Na}$ in their cation exchange complex. Nearly 800 million ha of land which accounts for $6 \%$ of the world's land is influenced by saline sodic soil [7]. Subsoil of sodic soil may be saturated with water while the surface is dry and hard. Salt stress imposes adverse impacts to almost all growth stages as well as metabolic processes in plants and ultimately ending up with a reduction in yield [8]. In plants, root is the first organ to be encounted by salt stress due to which water uptake is hindered, decline in water potential is triggered and finally leads to osmotic stress [9]. This disturbs the ionic balance and raises hyperosmotic stress in plants. Thus generation of excessive Reactive Oxygen Species (ROS) is accelerated which destroys genetic material and brings about substantial oxidation of important biomolecules like lipids, proteins as well as carbohydrates, finally triggers a change in their nature and functions which eventually hinders the growth of plant [10-12]. Increased amount of $\mathrm{NaCl}$ in plant cell organelles impedes the functions of various important enzymes such as carbonic anhydrase [13], Rubisco [14], nitrate reductase and various other enzymes which plays important role in metabolic activities of plants. Increased concentration of ROS declines the concentration of cytosolic $\mathrm{K}^{+}$, causes a major disruption in intracellular ionic homeostasis, which activates the enzymes like proteases and endonuclease $[15,16]$. Leaves also manifest salt stress by their reduced size, closure of stomata, damage of photosynthetic tools, electron transport chain as well as reduced photosynthetic pigments and lipid peroxidation $[17,18]$. The reduction in pigment content may be used as a stress marker in plants [19]. Bohra et al. [20] reported that salt stress is accountable for variation in osmotic and ionic homeostasis which ultimately harms the structural and functional proteins of plant cells.

Plants under saline stress display a complex oxidative defense strategy of enzymatic antioxidants such as super oxide dismutase (SOD), glutathione reductase (GR), peroxidase (POX), catalase (CAT), ascorbate peroxidase (APX), dehydroascorbate reductase and monodehydroascorbate dehydrogenase [21-23] and non-enzymatic antioxidants included ascorbate, glutathione, phenolics, flavonoids and tocopherols [24-28] that counter the destructive effect of ROS by scavenging and transforming them into less damaging forms. Proline is an important osmolytes that gets accumulated to encountered salt stress [29-31] by decreasing the cytoplasmic osmotic potential and maintaining the turgor pressure, which 
ultimately facilitates the water absorption. Proline functions as redox potential controller, defends biomolecules and is said as single osmolyte which has been revealed to scavenge ${ }^{1} \mathrm{O}_{2}$ (singlet oxygen) and other free radicals such as $\mathrm{OH}^{-}$[32]. High accumulation of proline in plants under salt stressed conditions is associated with tolerance to salt stress and is suggested as an important criterion for the selection of salinity tolerant genotypes [33,34]. The response of plants towards salinity stress also depends upon nature of salt, dose and variety.

The objective of present study is to analyse the morphological, physiological and biochemical attributes of two different varieties of chickpea subjected to salt stress for the identification of salt tolerant as well as salt sensitive variety. Selection of salt tolerant plants is one of the important strategies to overcome the problems of salt stress. In order to increase the cultivation of chickpea, it is necessary to understand the effects of salt stress on its morphological, physiological, biochemical attributes and root cell viability. Chickpea (Cicer arietinum L.) is considered as the third most valuable leguminous crop of the world and is valued for its protein rich seeds. It contains about $25.3 \%-28.9 \%$ protein content, nutrients like zinc, iron, calcium and vitamin K. Chickpea has various medicinal uses such as it can improve calcium absorption in bones and can reduce the risk of heart strokes by lowering the level of cholesterol. It enhances the soil fertility predominantly in the arid and low rainfall areas through the biological nitrogen fixation [35]. Principal mechanism of salinity tolerance is based on distinctive responses of varieties with divergent stress tolerance. Salt stress is one of the main hurdles to the productivity of chickpea (Cicer arietinum) and about more than $8 \%$ of yield loss occurs globally every year due to the salt stress [36]. Its sensitivity towards salt stress becomes a need of hour for the selection of salt tolerant and salt sensitive varieties to provide a choice for future crop production. The identification of varieties that show tolerance towards stress gives an initial germplasm base for breeding salt tolerant crops. The present work was conducted to assess the sensitivity and tolerance capability of two varieties of chickpea cultivated under salt stress, based on variability in their growth indicators, physiological parameters and antioxidant activities.

\section{Materials and Methods}

\subsection{Plant Material and Treatment Conditions}

Vigorous, fit seeds, homogenous in terms of size and color of two different varieties of Cicer arietinum namely Pusa-BG5023 and Pusa-BGD72 were acquired from IARI Pusa New Delhi. Before sowing, seeds were washed carefully with clean water and then surface sterilized with $0.01 \%$ mercuric chloride, rewashed with DDW in order to remove the adhered particles. Fifteen disinfected and sterilized seeds from both the varieties were sown in clay pots of $25 \times 25 \mathrm{~cm}$ size having equal quantity of soil and manure. The experiment was set in a complete randomized block design with replicates. Thinning was done on fifteen days after sowing and five plants were maintained in each pot. Five treatments of salt were given in the form of $0 \mathrm{mM}$ (control), 50,100, 150, and $200 \mathrm{mM}$ of sodium chloride solution in equal quantity on $20^{\text {th }}$ day after sowing. While control plants were irrigated with tap water. The pots were placed in net house of Botany department A.M.U. Aligarh. Sampling was done on 45 days after sowing (DAS) to observe the following parameters.

\subsection{Morphological Parameters}

After 45 days of sowing, two plants per treatment were taken for the evaluation of growth or morphological parameters and washed with tap water carefully in order to wipe out the adhered soil particles without disturbing roots. The root length and shoot length of plants was measured with the help of scale in centimeters. The root and shoot samples were blotted and then placed in an oven for a period of $72 \mathrm{~h}$ at temperature of $80^{\circ} \mathrm{C} \pm 2{ }^{\circ} \mathrm{C}$ in order to measure the dry biomass of samples with the help of electronic balance (CY204, Scalteo Ins., Germany). The number of nodules per root system was counted 
on fresh roots. Arbitrarily chosen leaves from each sample were taken and used to calculate the leaf area. Leaf area was recorded with the help of leaf area metre (LA211, Systronics, Ahmedabad, India).

\subsection{Total Chlorophyll and Carotenoid Contents}

Total chlorophyll and carotenoid contents in fresh leaves was estimated by the method described by [37]. For the estimation of chlorophyll and carotenoid, $100 \mathrm{mg}$ of washed fresh leaves were crushed in $10 \mathrm{ml}$ of $80 \%$ acetone and filtered. Absorbance was recorded at 663 and $645 \mathrm{~nm}$ for chlorophyll estimation and at 480 and $510 \mathrm{~nm}$ for carotenoid estimation using UV-Visible spectrophotometer. The total chlorophyll and carotenoid content was calculated using the following formula:

Total Chlorophyll content $=20.2($ OD 645$)+8.02($ OD 663$) \times \frac{\mathrm{V}}{\mathrm{W}} \times 1000 \mathrm{mg} \mathrm{g}^{-1} \mathrm{FW}$

Carotenoid content $=7.6(\mathrm{OD} 480)-1.49(\mathrm{OD} 510) \times \frac{\mathrm{V}}{\mathrm{d}} \times \mathrm{W} \times 1000 \mathrm{mg} \mathrm{g}^{-1} \mathrm{FW}$

\subsection{Malondialdehyde (MDA) Content}

Lipid peroxidation in leaves was assessed by the method proposed by [38]. $500 \mathrm{mg}$ of fresh leaves were weighed, ground in $0.1 \%$ trichloroacetic acid (TCA) and centrifuged for $5 \mathrm{~min}$ in order to separate the solid and liquid matter of homogenate. The supernatant was taken in a test tube and $0.5 \%$ thiobarbituric acid (TBA) was added. The reaction mixture was heated to $100^{\circ} \mathrm{C}$ for $30 \mathrm{~min}$, immediately cooled in an ice bath and again centrifuged at $12,000 \mathrm{rpm}$ for $5 \mathrm{~min}$. The optical density of supernatant was taken at wavelength of 532 and $600 \mathrm{~nm}$ on spectrophotometer. The malondialdehyde MDA content was calculated by subtracting the optical density at $600 \mathrm{~nm}$ from $532 \mathrm{~nm}$, using a specific extinction coefficient of $155 \mathrm{mM}^{-1} \mathrm{~cm}^{-1}$ and expressed as nmole $\mathrm{g}^{-1}$ fresh weight of the sample.

\subsection{Nitrate Reductase (NR) and Carbonic Anhydrase (CA) Activity}

The nitrate reductase activity was determined by the method proposed by [39]. Fresh leaf material from every treatment was chopped and kept in plastic vials. Potassium nitrate and phosphate buffer was added to it, followed by addition of isopropanol at a $\mathrm{pH}$ of 7.5. The samples were incubated for $2 \mathrm{~h}$ at $30^{\circ} \mathrm{C}$. N-1-naphthyl ethylenediamine dihydrochloride and sulphanilamide solution were added to $4 \mathrm{ml}$ of incubated mixture and left for $20 \mathrm{~min}$ at room temperature for development of pink color. Optical density was recorded at $540 \mathrm{~nm}$. The readings that we got from spectophotometer were then compared with calibrated curve and activity of enzyme nitrate reductase was expressed in $\mathrm{n} \mathrm{mol} \mathrm{NO} \mathrm{g} \mathrm{g}^{-1} \mathrm{FM} \mathrm{s}^{-1}$ on the basis of fresh mass.

Carbonic anhydrase activity was determined by the method of Dwivedi et al. [40]. The leaf materials taken from every treatment of both the varieties were separately chopped and placed in plastic vials. $10 \mathrm{ml}$ of cysteine hydrochloride was added to it and incubated for $20 \mathrm{~min}$ at $4{ }^{\circ} \mathrm{C}$ and filtered. The solution was discarded and filtrate was transferred to new cleaned test tubes into which $4 \mathrm{ml}$ of phosphate buffer ( $\mathrm{pH}$ 6.8), sodium bicarbonate solution and bromothymol blue indicator was added. The test tubes were again incubated at $4^{\circ} \mathrm{C}$ for $20 \mathrm{~min}$. In the reaction mixture few drops of methyl red indicator was added and titrated against $0.05 \mathrm{~N} \mathrm{HCl}$. The enzyme activity was calculated by the difference between sample reading and control reading.

\subsection{Protein Estimation}

Estimation of total soluble protein content was performed by the method of Bradford [41]. The leaf material was homogenized and centrifuged, and $200 \mu \mathrm{L}$ supernatant was collected in test tubes to which 
$4 \mathrm{ml}$ of Bradford reagent was added and incubated at $25^{\circ} \mathrm{C}$ for $10 \mathrm{~min}$. The absorbance of the solution was recorded on a spectrophotometer at $595 \mathrm{~nm}$.

\subsection{Proline Content}

The estimation of proline content in fresh leaves was observed by the protocol proposed by Bates et al. [42]. For the extraction of sample, fresh leaf samples dissected from plants were washed and homogenized in $5 \mathrm{ml}$ of $3 \%$ sulphosalicylic acid. The homogenate obtained was filtered with the help of Whatman filter paper No. 2 and collected in test tube. Two $\mathrm{ml}$ of extract was taken in test tube followed by addition of $2 \mathrm{ml}$ of glacial acetic acid and $2 \mathrm{ml}$ of ninhydrin. The reaction mixture was heated in boiling water bath at $100^{\circ} \mathrm{C}$ for $20 \mathrm{~min}$. The reaction was terminated, cooled by transferring the test tubes immediately in ice bath. Then after, $4 \mathrm{ml}$ of toluene was added to each test tube containing the reaction mixture with vigorous shaking for 20-30 s. The chromophore (toluene) layer was separated and kept at room temperature. The absorbance of red color was measured at $520 \mathrm{~nm}$ against blank reagent using spectrophotometer. The amount of proline in the sample was calculated by using a standard curve prepared from pure proline and expressed on the basis of fresh mass of sample.

\subsection{Analysis of Enzymatic Antioxidants}

Fresh leaf material $(1 \mathrm{~g})$ was ground in $5 \mathrm{ml}$ of $50 \mathrm{mM}$ of potassium phosphate buffer $(\mathrm{pH} 7.0), 1 \mathrm{mM}$ phenylmethanesulfonylflouride, $1 \mathrm{mM}$ EDTA, $2 \%$ polyvinyl pyrrolidone and $0.5 \%$ Triton X-100. The homogenate was centrifuged at $15,000 \mathrm{rpm}$ for 10 min at $5^{\circ} \mathrm{C}$ and supernatant was collected for the estimation of different types of antioxidant enzymes. The supernatant was collected and used for the evaluation of enzymes.

The POX activity was measured by the method of Sanchez et al. [39,43]. $50 \mathrm{mM}$ phosphate buffer with $\mathrm{pH} 7.0,20 \mathrm{mM}$ guaiacol, $15 \mathrm{mM} \mathrm{H}_{2} \mathrm{O}_{2}$ and $0.1 \mathrm{ml}$ of enzyme extract were mixed. The enzyme activity was observed by recording the change in absorbance at $436 \mathrm{~nm}$ on a spectophotometer for $1 \mathrm{~min}$ at $25^{\circ} \mathrm{C}$.

Catalase activity was estimated by the method proposed by Aebi [44] with slight changes. $50 \mathrm{mM}$ of phosphate buffer, $15 \mathrm{mM} \mathrm{H} \mathrm{H}_{2}$ and $0.1 \mathrm{ml}$ of enzyme extract was added. The reduction in hydrogen peroxide was observed by decrease in optical density at $240 \mathrm{~nm}$ for a minute with interval of $30 \mathrm{~s}$ at $25^{\circ} \mathrm{C}$. Extinction coefficient of $0.036 \mathrm{mM}^{-1} \mathrm{~cm}^{-1}$ was used for calculation of catalase activity.

Superoxide dismutase activity was estimated according to the method of Beauchamp and Fridovich [45]. About $40 \mu \mathrm{L}$ of enzyme extract was transferred in test tubes to which $50 \mathrm{mM}$ phosphate buffer ( $\mathrm{pH} 7.8$ ), $55 \mu \mathrm{M}$ NBT, $9.9 \mathrm{mM}$ L- methionine, $2 \mathrm{mM}$ EDTA and $0.02 \%$ Triton X-100 were added. To this reaction mixture, riboflavin was added at last in complete dark condition. The activity of SOD depends upon its capability to decrease the photochemical reduction of nitro-blue tetrazolium, by reading the absorbance at $560 \mathrm{~nm}$ for $2 \mathrm{~min}$ at $25^{\circ} \mathrm{C}$.

\section{Reactive Oxygen Species Estimation}

Superoxide radical $\mathrm{O}_{2}^{--}$production was estimated by following the histochemical staining protocol of Kaur et al. [46] using stain nitrozolium blue tetrachloride (NBT). The leaf samples were immersed in $6 \mathrm{mM}$ nitrozolium blue tetrachloride solution prepared in sodium citrate buffer and incubated for $8 \mathrm{~h}$ at room temperature. The samples were then removed from the NBT solution, dipped in $100 \%$ ethanol and boiled at $100^{\circ} \mathrm{C}$ till chlorophyll was removed. After cooling, samples were transferred to $20 \%$ glycerol and images were captured with NIKON digital camera (COOLPIX110). 


\section{Confocal Microscopic Study for Cell Viability}

Uprooted plants were washed thoroughly with tap water in order to remove the adhered soil. Cleaned roots were cut with sharp knife and dipped in propidium iodine dye $(5 \mu \mathrm{M})$ for 30-35 min. Stained roots were put on fresh glass slides and observed under confocal microscopy.

\section{Scanning Electron Microscopy}

The effect of salinity on stomata was also examined with the help of scanning electron microscopy (JEOL JSM-JSM 6510). Fresh leaf samples were first fixed in $2.5 \%$ glutaraldehyde buffer (pH 7.3 ) for $2 \mathrm{~h}$ followed by post-fixing in 1\% osmium oxide. Fixed samples were dehydrated in graded series of ethanol $(50 \%, 70 \%, 80 \%, 90 \%$ and $100 \%)$ and dehydrated samples were coated with gold-palladium and observed at a magnification of $250 \mathrm{X}$ and $3000 \mathrm{X}$ through scanning electron microscopy.

\section{Statistical Analysis}

The obtained five biological replicates from each treatment and control were subjected to statistical analysis. Variance analysis was employed through ANOVA and the data was further processed using the SPSS software (17.0 Version). Moreover, to study the significance at $5 \%$ of probability level, the mean data was compared through Duncan multiple range test.

\section{Results}

\subsection{Effect of Salt Stress on Growth Characteristics}

Growth parameters of two chickpea varieties were calculated in terms of root length, shoot length, root and shoot dry weight, number of nodules per root system and leaf area per plant. The results of growth parameters of both the two varieties of chickpea at five different treatments of $\mathrm{NaCl}$ are depicted in Figs. 1a-1d, 2a and 2b. Our results indicated that increasing doses of $\mathrm{NaCl}$ decreased all of the growth parameters of both the chickpea varieties at 45 days of sowing. Among all the salt treatments, plants supplemented with higher treatment of $\mathrm{NaCl}(200 \mathrm{mM})$ displayed a remarkable decline in all the growth parameters followed by 150,100 and $50 \mathrm{mM}$ of $\mathrm{NaCl}$. However, among two varieties of chickpea, variety BG-5023 of chickpea showed least reduction in all growth parameters while variety BGD-72 of chickpea showed maximum decrease. The percent reduction in root length of BG-5023, and BGD-72 was $40.63 \%$ and $62.24 \%$, respectively at 45 DAS, over their controls (Fig. 1a). Similarly, the percent reduction of shoot length of BG-5023 and BGD-72 was $47.65 \%$ and $74.09 \%$ over their controls, respectively (Fig. 1b).

Results of dry biomass of root and shoot of chickpea varieties as supplemented by five doses of $\mathrm{NaCl}$ are presented in (Figs. 1c and 1d). Both the root and shoot dry weight of chickpea varieties were reduced significantly at $200 \mathrm{mM}$ of salt by percentage of $51.83 \% ; 37.61 \%$ in Pusa-BG5023 and $75.33 \% ; 81.29 \%$ in Pusa-BGD-72, respectively, over their control.

Leaf area and number of nodules per root system of two chickpea varieties as influenced by five salt treatments are shown in Figs. $2 \mathrm{a}$ and $2 \mathrm{~b}$. Our results clearly revealed that $\mathrm{NaCl}$ significantly decreased the leaf area and number of nodules per plant. However, among two varieties, Pusa-BG5023 variety showed least decrease while as variety Pusa-BGD72 showed maximum decrease. The percent reduction in leaf area and number of nodules per plant at $200 \mathrm{mM}$ of $\mathrm{NaCl}$ was $40.82 \%$; $45.13 \%$ in BG-5023 and $60.58 \% ; 70.11 \%$ in BGD-72, respectively, over their controls at 45 DAS. 

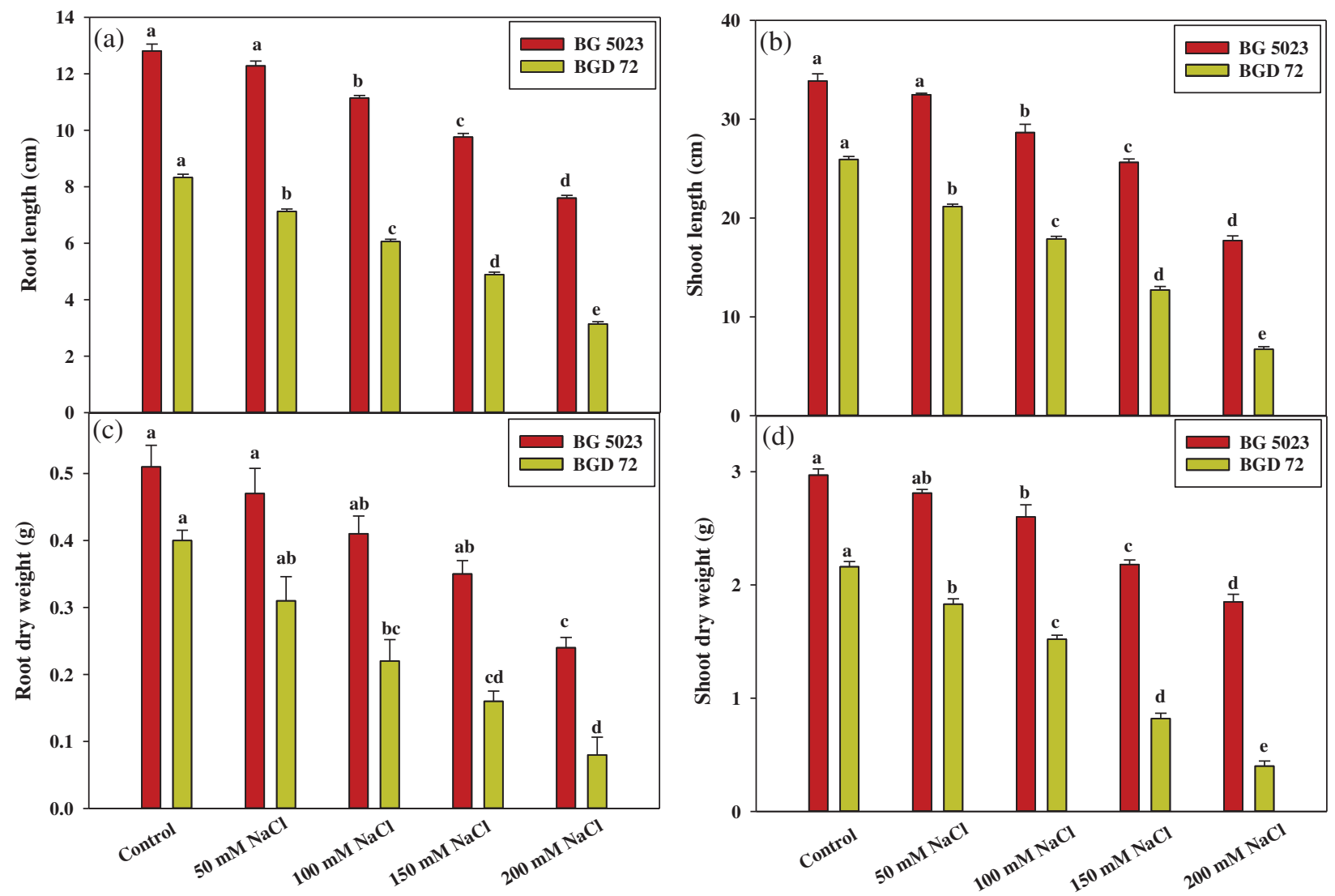

Figure 1: Effect of different concentrations of ( $\mathrm{NaCl})$ on (a) root length; (b) shoot length; (c) root dry weight and (d) shoot dry weight of two Cicer arietinum varieties at 45 days after sowing. Small letters from (a-e) represent variation among treatments with respect to control and also the values with different letters are significantly different $(p<0.05$, Duncan's)

\subsection{Effect of Salt Stress on Physiological and Biochemical Attributes}

\subsubsection{Total Chlorophyll and Carotenoid Content}

The results of total chlorophyll and carotenoid content of two chickpea varieties treated with five different doses of $\mathrm{NaCl}$ are presented in Figs. 2c and 2d. Our results showed that total chlorophyll and carotenoid content of both the chickpea varieties decreased significantly with the increasing levels of $\mathrm{NaCl}$. The percent reduction in total chlorophyll and carotenoid content was highest in variety PusaBGD72 and least in variety Pusa-BG5023. A reduction of $38.09 \% ; 45.13 \%$ and $61.78 \% ; 61.26 \%$ in total chlorophyll and carotenoid content was observed in Pusa-BG5023 and Pusa-BGD72, respectively, over their controls at $45 \mathrm{DAS}$ due to application of $200 \mathrm{mM}$ of $\mathrm{NaCl}$.

\subsubsection{Effect of Salt Treatment on MDA Level}

Lipid peroxidation was estimated in terms of malondialdehyde (MDA) content in the leaves of chickpea. This test was assessed in order to check the level of stress in two varieties of chickpea against salt treatments viz. 50,100, 150 and $200 \mathrm{mM}$ of $\mathrm{NaCl}$ at 45 days after sowing. Percent lipid peroxidation increased with the increase in the level of salt dose. The increase in MDA content was $67.98 \%$ in Pusa-BG-5023 and $45.88 \%$ in Pusa-BGD-72, respectively, over their respective control due to $200 \mathrm{mM}$ of $\mathrm{NaCl}$ at 45 DAS (Fig. 3a). Among two varieties Pusa-BG5023 was proved to be least sensitive and Pusa-BGD72 was considered as salt most sensitive variety. 

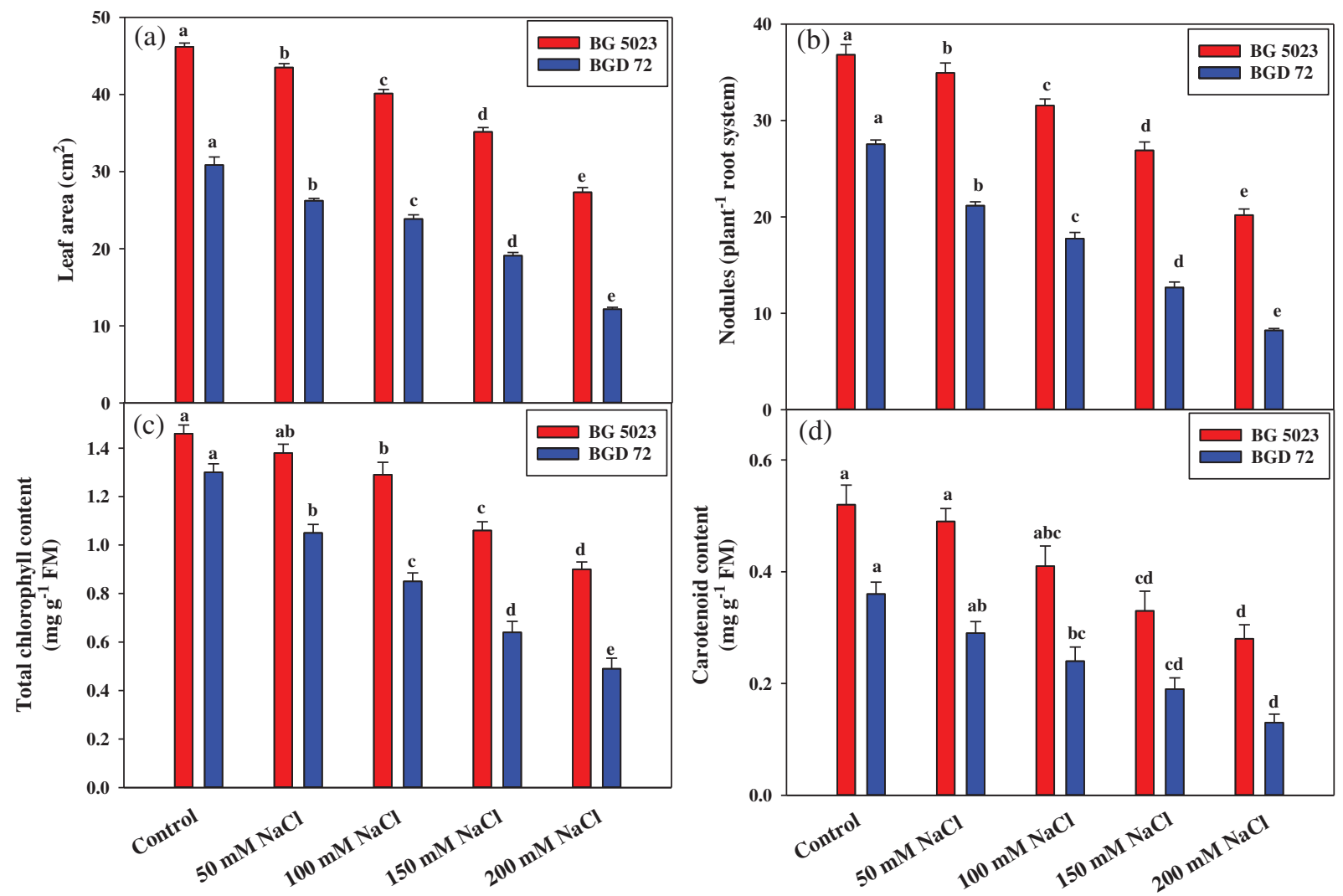

Figure 2: Effect of different concentrations of $(\mathrm{NaCl})$ on (a) leaf area per plant; (b) number of nodules per root system; (c) total chlorophyll content; and (d) carotenoid content of Cicer arietinum varieties at 45 days after sowing. Small letters from $(\mathrm{a}-\mathrm{e})$ represent variation among treatments with respect to control and also the values with different letters are significantly different $(p<0.05$, Duncan's)

\subsubsection{Effect of Salinity on Carbonic Anhydrase Activity}

Carbonic anhydrase activity (CA) changed extensively in response to different levels of $\mathrm{NaCl}(0,50$, $100,150$, and $200 \mathrm{mM})$ at $45 \mathrm{DAS}$ in both the varieties. $200 \mathrm{mM}$ of $\mathrm{NaCl}$ induced a decline of $(72.65 \%)$ in Pusa-BGD72 and (45.14\%) in Pusa-BG5023 as compared to their control plants (Fig. 3d). This in turn ensures that Pusa-BD5023 had greater endurance to salt stress as compared to Pusa-BGD72.

\subsubsection{Nitrate Reductase Activity}

The present results showed that enzymatic activity of nitrate reductase fluctuates extensively in response to varying levels of salinity at $45 \mathrm{DAS}$. The lowest salt concentration $50 \mathrm{mM}$ was proved least toxic to PusaBG5023 showing a decline of $6.44 \%$ in nitrate reductase activity. However, Pusa-BGD72 was highly sensitive at this treatment and showed a reduction of $18.22 \%$, in the NR activity (Fig. 3c). Thus, the results indicated that Pusa-BD5023 shows greater salinity avoidance compared to Pusa-BGD72 variety.

\subsubsection{Leaf Protein Content}

Leaf protein content of two chickpea varieties supplemented with various $\mathrm{NaCl}$ treatments are presented in (Fig. 3b). Our results clearly indicated leaf protein content decreased with the increase of salt concentration. However, least decrease was observed at less concentration $(50 \mathrm{mM}$ of $\mathrm{NaCl})$. The percent reduction in leaf protein content was highest (62.54\%) in Pusa-BGD72 and was found $(48.33 \%)$ in PusaBG5023 at $200 \mathrm{mM}$ of $\mathrm{NaCl}$ at growth stage of 45 days over their control. 

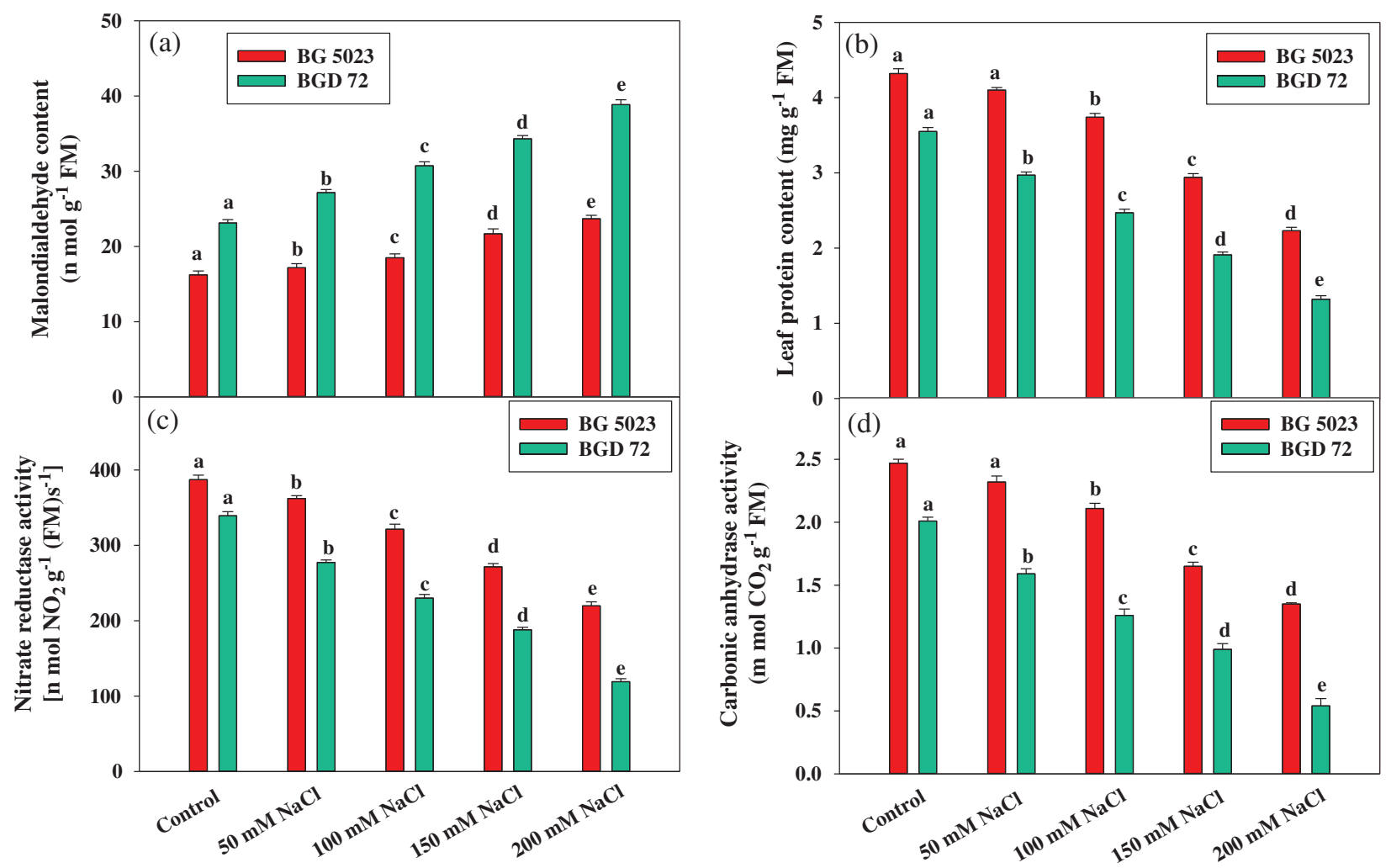

Figure 3: Effect of different concentrations of $(\mathrm{NaCl})$ on (a) Malondialdehyde content (b) Leaf protein content; (c) Nitrate reductase activity; and (d) Carbonic anhydrase activity of Cicer arietinum varieties at 45 days after sowing. FM on Y-axis represents fresh biomass. Small letters from (a-e) represent variation among treatments with respect to control and also the values with different letters are significantly different $(p<0.05$, Duncan's)

\subsubsection{Proline Content}

Plants fed with $\mathrm{NaCl}$ displayed higher leaf proline content (Fig. 4a). The amount of proline was lowest in control plants and showed an increase with the increase in the concentration of the salt. The plants that were treated with $200 \mathrm{mM}$ of $\mathrm{NaCl}$ in soil exhibited maximum values in both the varieties and the increment was 49.37\% and 27.16\% in Pusa-BG5023 and Pusa-BGD72, respectively, over the respective controls.

\subsubsection{Antioxidant Enzyme Activities}

The results shown in Figs. 4b-4d distinctly represented that both the two varieties of chickpea showed an increase in enzymatic antioxidant activity supplement with five different doses of NaCl. Among two varieties of chickpea, Pusa-BG5023 showed significant increase in the enzymatic activities of CAT, SOD and POX in response to five different treatments of $\mathrm{NaCl}$. However, insignificant enzymatic activity of CAT, SOD and POX was observed in Pusa-BGD72 respectively, over its control. The percent increase of CAT, SOD and POX due to $200 \mathrm{mM}$ of $\mathrm{NaCl}$ in variety BG-5023 and BGD-72 was $50.08 \% ; 33.15 \%$, $(52.11 \% ; 33.18 \%)$ and $(48.54 \% ; 26.15 \%)$ respectively over their control. 

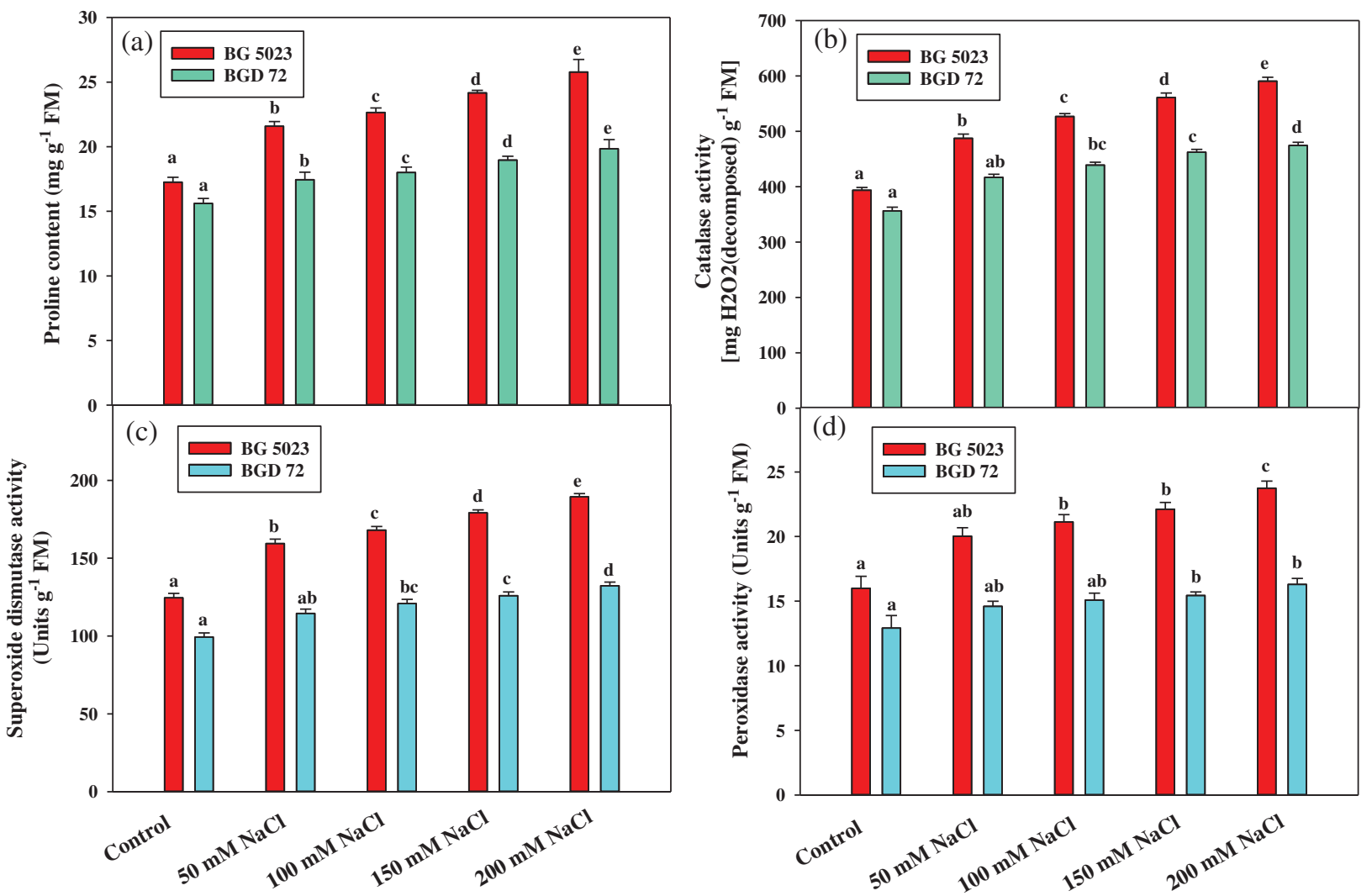

Figure 4: Effect of different concentrations of $(\mathrm{NaCl})$ on (a) Proline content; (b) Catalase activity; (c) Superoxide dismutase activity; and (d) Peroxidase activity of Cicer arietinum varieties at 45 days after sowing. FM on Y-axis represents fresh biomass. Small letters from (a-e) represent variation among treatments with respect to control and also the values with different letters are significantly different $(p<0.05$, Duncan's $)$

\section{Production of Superoxide Radicals $\left(\mathrm{O}_{2}{ }^{--}\right)$}

Generation of $\mathrm{O}_{2}{ }^{--}$in leaves of 45 days old plants of two different varieties of chickpea treated with $\mathrm{NaCl}$ were shown in Fig. 5 by blue coloured spots on leaf surfaces. Pusa-BGD72 represents sharp and more pronounced spots as compared to Pusa-BG5023 due to excessive accumulation of superoxide radicals and also the number of spots enhanced with the increasing levels of salt being maximum at $200 \mathrm{mM} \mathrm{NaCl}$ as compared to control leaves.

\section{Confocal Studies}

The viability of cell could be analyzed visually with the help of Propidium iodine dye that penetrates the damaged cell membrane and stains nucleic acid which is visible inside the dead cells of roots as red fluorescent spots (Fig. 6). Cell viability decreases with increase in concentration of $\mathrm{NaCl}(0,50,100,150$, and $200 \mathrm{mM}$ ). In the present investigation, roots treated with $200 \mathrm{mM}$ of $\mathrm{NaCl}$ concentration displayed greater number of dead cells in the form of red spots which were prominent in both varieties. However, the variety Pusa-BG5023 showed less spots as compared to Pusa-BGD72 at $200 \mathrm{mM}$ of $\mathrm{NaCl}$ concentration conferring its tolerance towards salinity. 


\section{Superoxide Radical Images}

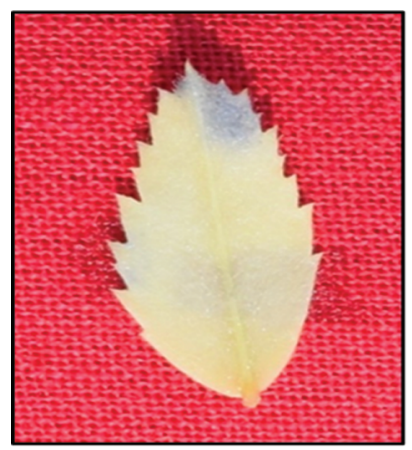

(A)

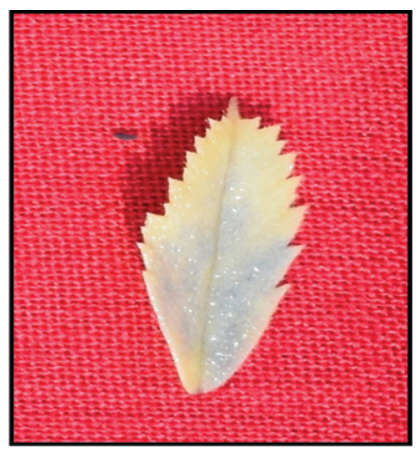

(B)

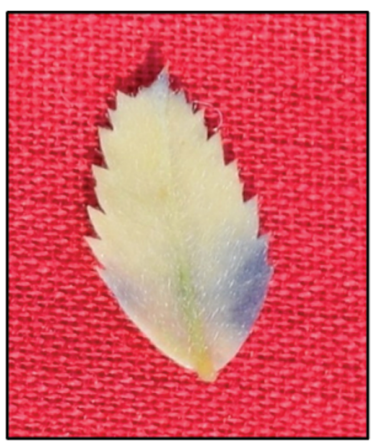

(C)

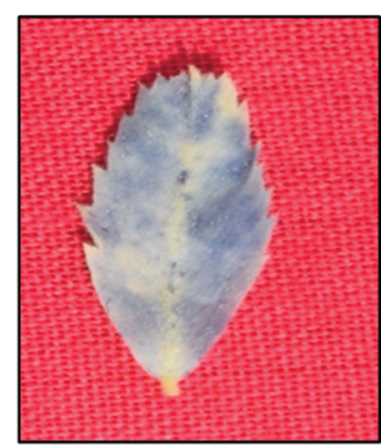

(D)

Figure 5: Localization of superoxide ions produced by tetrazolium chloride (NBT) in 45 days old leaves of two varieties of Cicer arietinum are depicting as blue spots on leaf surface. Image (A), (B) represents control, $200 \mathrm{mM} \mathrm{NaCl}$ treated leaves of variety BG 5023 and (C), (D) represents control, $200 \mathrm{mM} \mathrm{NaCl}$ treated leaves of variety BGD 72

\section{Confocal Microscopic Images}
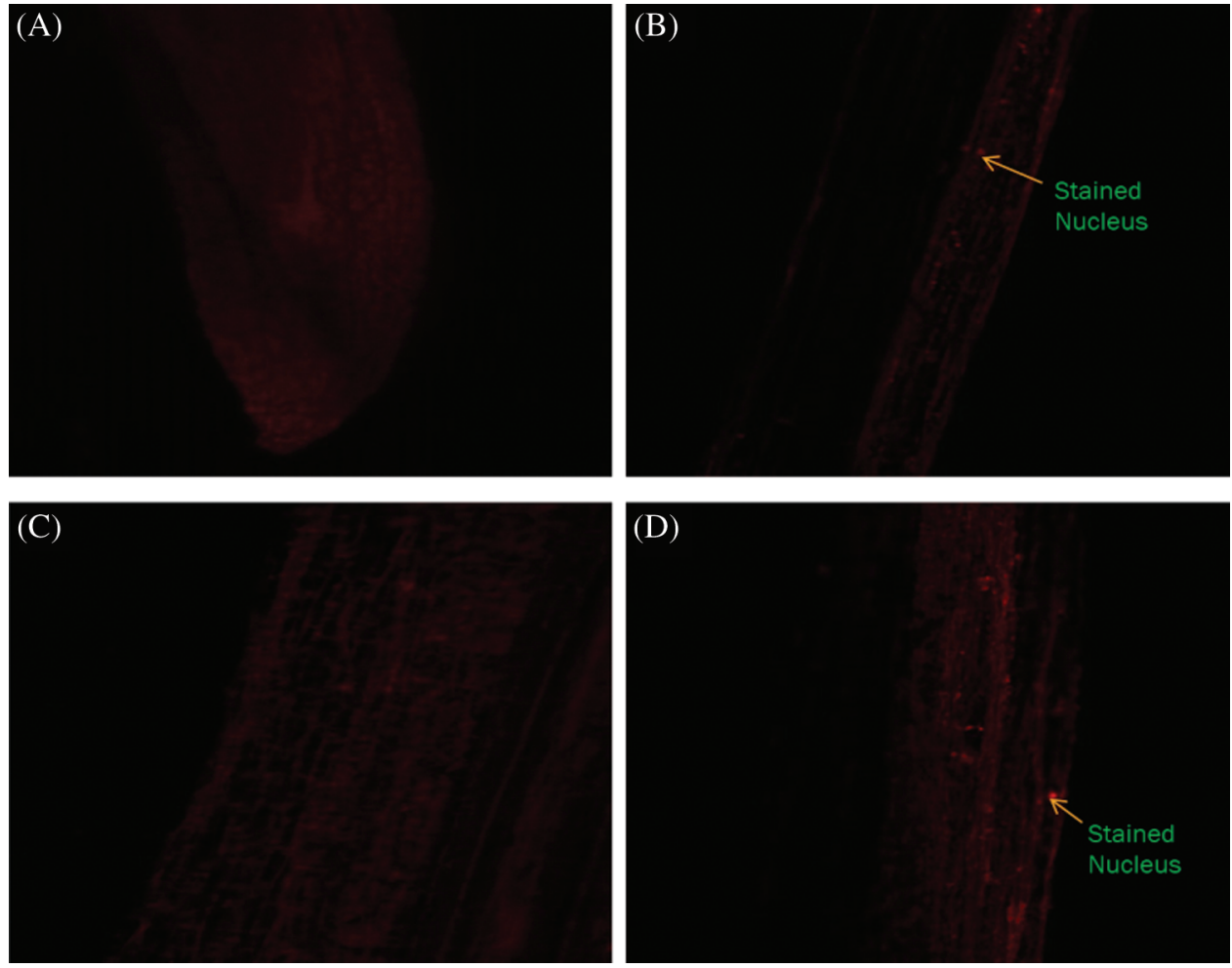

Figure 6: Cell viability test was performed on 45 days old roots of two varieties of Cicer arietinum and confocal microscopic images were obtained. Large number of stained nuclei indicates less cell viability. (A) Control and (B) $200 \mathrm{mM} \mathrm{NaCl}$ are confocal images of variety BG 5023 while as (C) control and (D) $200 \mathrm{mM}$ are confocal images of variety BGD 72 


\section{SEM Imaging}

Stomatal behavior was affected in both the varieties of chickpea due to salt stress. Leaves of 45 day old Pusa-BG5023 and Pusa-BGD72 varieties of chickpea treated with $200 \mathrm{mM} \mathrm{NaCl}$ showed reduced stomatal aperture as compared to their control. However, highly reduced stomatal apertures were being displayed in the leaves of Pusa-BGD72 as compared to Pusa-BG5023 which confers its more sensitivity towards salt stress (Fig. 7).

\section{SEM Images}
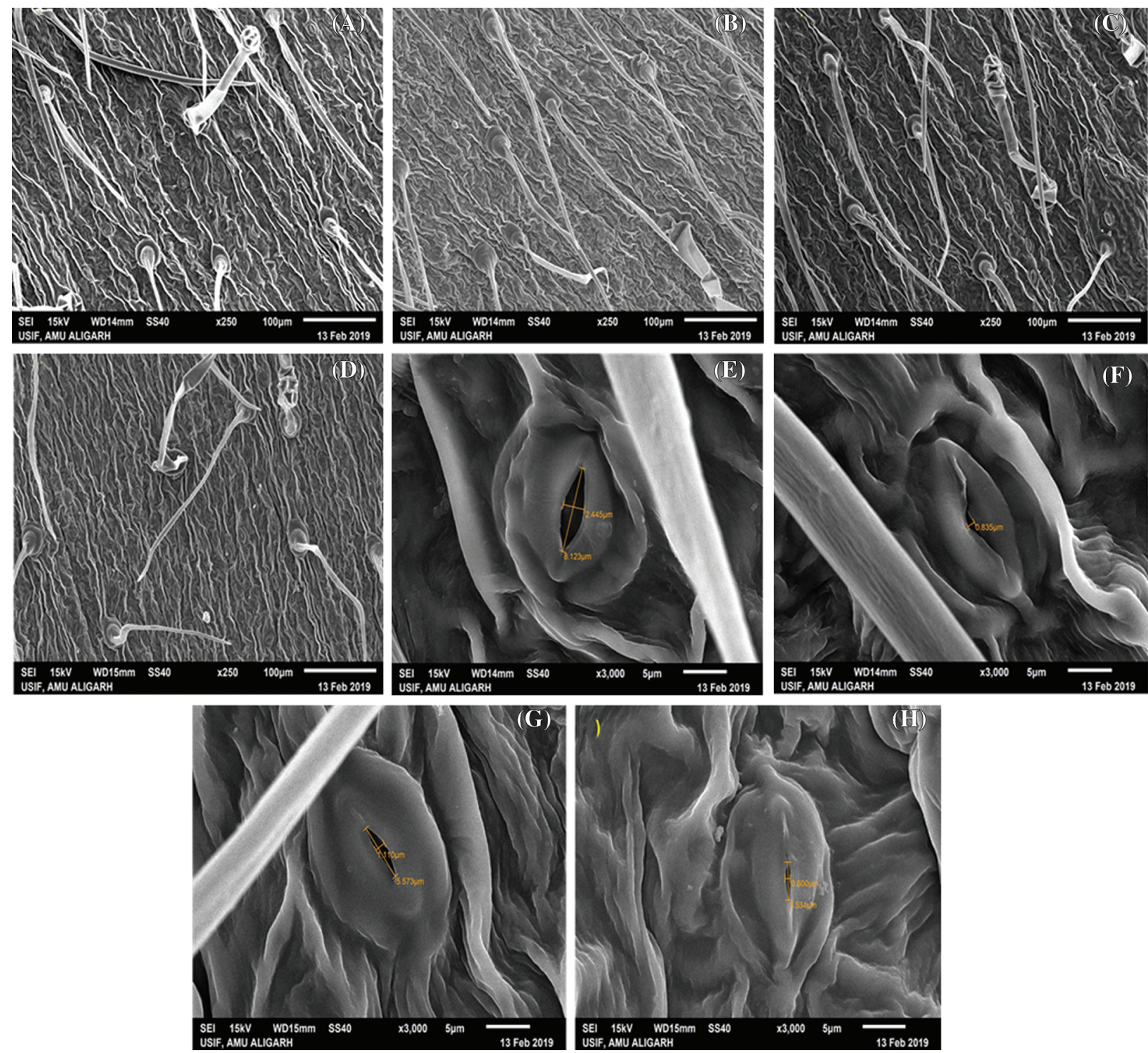

Figure 7: Scanning electron microscope (SEM) images of stomata: Response of stomatal aperture of 45 days old two varieties of Cicer arietinum leaves to the $\mathrm{NaCl}$ treatment was studied using Scanning electron microscope (SEM). (A) and (B) represents control and $200 \mathrm{mM} \mathrm{NaCl}$ treated leaves of variety BG 5023, (E) and (F) represents control and $200 \mathrm{mM} \mathrm{NaCl}$ treated leaves of variety BGD 72 at 250X magnification respectively and (C), (D), (G) and (H) represents their magnified images at 3000X, respectively 


\section{Discussion}

Studies have shown that plants grown under saline environments have adverse influence on productivity, quality and survival rate [47]. Salt stress in plants cause osmotic stress, disorders in mineral nutrition, alteration of membrane permeability, production of reactive oxygen species (ROS) and further inhibits the activity of different enzymes. This in turn causes disorders in physiological and biochemical mechanisms which finally hinders the plant growth and development [48].

Growth parameters like root length, shoot length, fresh and dry weight are typically used to assess plant tolerance to various types of abiotic stresses. The decline in growth under salt stress is due to decrease in osmotic potential, leading to stomatal closure. Furthermore, it interferes with the ability of plants to pull water from the soil via roots [49] and hinders the maintenance of turgor pressure due to excessive accrual of sodium and chloride ions in the tissues of plant [50,51]. According to Jamil et al. [52] root and shoot length are the major indicators of salt stress. In present study, it was determined that increase in $\mathrm{NaCl}$ concentration has deleterious impact on growth of both the varieties of chickpea. However, the response of salt stress on growth characteristics of the two varieties (Pusa-BGD72 and Pusa-BG5023) was variable. Pusa-BGD72 was capable of enduring the salinity stress up to $50 \mathrm{mM}$, as observed at 45 DAS, hence may be termed as a sensitive variety. On the other hand, Pusa-BG5023 was very least affected by the salt concentration up to $100 \mathrm{mM}$ as observed at $45 \mathrm{DAS}$, and hence may be termed as tolerant variety. The cause for reduced plant growth is due to toxic effects of the $\mathrm{NaCl}$ as well as unbalanced nutrient uptake by the roots. High concentration of salt in root area zone slows down the water uptake capability and further inhibits the elongation of root and shoot. An increased salt tolerance is correlated to low rate of $\mathrm{Na}^{+}$and $\mathrm{K}^{+}$uptake. Confocal study also indicated that salt stress increases the damage and death of roots cells. Similar reports of reduction of plant growth under saline conditions have been observed in Vigna aconitifolia L. [53], Raphanus sativus L. [54], and Vigna unguiculata L. [55] Oryza sativa [56] and in tomato seedlings [57]. The number of nodules per root system also showed a significant decline with increasing level of sodium chloride in soil. Salinity decreases the colonization of Rhizobium and root hair formation in leguminous plants. Reduction in number of root nodules per root system due salinity was also observed in Cicer arietinum [58].

Biomass accumulation is one of the indispensable indicators for screening salt tolerance in plants [59]. Generally, plants that are susceptible to salt stress accumulate bulk of $\mathrm{Na}^{+}$ions in their tissues as compared to those plants that show tolerance towards the salinity [60]. The present investigation showed maximum decrease in dry biomass in Pusa-BGD72 as compared to Pusa-BG5023. The possible reason behind this decline may be due to salt-induced rise in osmotic stress that inhibits the uptake of essential plant nutrients, water uptake and reduction in activity of various important enzymes that helps the plants to resist the stress. Yousuf et al. [61] observed that decline in biomass accumulation under salt stress was probably due to nutrient imbalance and osmotically induced water stress. Our results are also in agreement with Hayat et al. [62] who showed that salinity caused a marked decrease in fresh and dry weight of various genotypes of Brassica juncea.

The results obtained in our study of decrease in total chlorophyll and carotenoid content are in consensus with previous works of Abdul Qados [63], in chickpea and Taibi et al. [64] in Phaseolus vulgaris. The decrease in chlorophyll level in salt-stressed plants may be due to changes of stomatal conductance of leaves, breakdown of pigment protein complex and inhibition of the uptake of magnesium ions, a chief constituent of chlorophyll and important for its synthesis. Carotenoids captures the light energy for the process of photosynthesis in plants, plays important role in the removal of triplet chlorophyll molecules as well as oxygen radicals and drives out the excess heat through xanthophyll cycle. Salinity-induced decline in carotenoid content was observed in both the varieties, being maximum in PusaBGD72 compared to Pusa-BG5023, illustrating its tolerance towards salinity. 
Soil salinity adversely affects the physiological attributes like protein synthesis as well. Total soluble protein content in plants is one of important indicator of physiological status of plants. In my present investigation, soil salinity adversely affects the total soluble protein content. However, this decrease was less and insignificant up to $50 \mathrm{mM}$ of sodium chloride in Pusa-BG5023 as compared to Pusa-BGD72, indicating its sensitivity for salt stress. The decline in protein content with increased concentration of $\mathrm{NaCl}$ is mostly ascribed to elevated level of reactive oxygen species that causes fragmentation and peroxidation of proteins. The protein content under saline conditions has also been reported to decrease in Oryza sativa [65], Paspalum scrobiculatum [66] and Brassica juncea [67].

Lipid peroxidation, measured in terms of malondialdehyde (MDA) content is generally recognized indicator of oxidative damage. Increased $\mathrm{Na}^{+}$and $\mathrm{Cl}^{-}$content in cell organelles cause accumulation of MDA that finally damage the polyunsaturated fatty acids (PUFA) of membrane lipids, change the membrane stability and replace $\mathrm{K}^{+}$as well as $\mathrm{Ca}^{2+}$ that obstruct the function of membrane proteins $[68,69]$. In our study, variety Pusa-BG5023 grown under salt stress accrued comparatively minor quantity of MDA than other variety, representing its greater competence in regulating the stress. On the contrary, the extreme MDA content was detected in Pusa-BGD72 showing its more vulnerability to lipid peroxidation. Our results are in agreement with the results of [70] in rice and [71] in Lemna minor.

Carbonic anhydrase (CA) and Nitrate reductase (NR) are important enzymes of plants. Carbonic anhydrase hydrates about 106 molecules of $\mathrm{CO}_{2}$ per second and plays an important role in mechanism of photosynthesis. This enzyme provides the supply of $\mathrm{CO}_{2}$ to Rubiusco in $\mathrm{C}_{3}$ plants and phosphoenolpyruvate carboxylase in $\mathrm{C}_{4}$ as well as in CAM plants. In the present study, salinity affects the activity of carbonic anhydrase in both of two varieties, but the activity of this enzyme was highly affected in variety Pusa-BGD72 as compared to Pusa-BG5023. The possible reason of decline in the activity of CA might be inferred to decreased concentration of internal carbon dioxide caused by the closure of stomata under salt stress. Nitrate reductase is a molybdenum containing enzyme that reduces nitrate $\left(\mathrm{NO}_{3}{ }^{-}\right)$to nitrite $\left(\mathrm{NO}_{2}{ }^{-}\right)$which is important for the production of protein. Salinity has adverse impact on its activity. Its activity depends upon nitrate level which acts both as the substrate of this enzyme as well as metabolic state of plant [72]. Findings of our result showed a decline in the activity of this enzyme under different concentrations of salt and $200 \mathrm{mM}$ of $\mathrm{NaCl}$ concentration proved to be the most deleterious to both varieties. However, Pusa-BGD72 exhibited more severe effect as compared to Pusa-BG5023 towards damage caused due to salt stress. The possible reason may be the increased concentration of sodium chloride interferes with nitrogen acquisition, utilization in plants and increased amount of chloride ions in membrane competes with nitrate. Therefore, the availability of main substrate nitrate is decreased and ultimately the activity of this enzyme is reduced. Our results are in agreement with [62] who also found similar results in Brassica juncea due to salinity.

Under normal conditions, plants generate low levels of reactive oxygen species in chloroplast, mitochondria and peroxisomes from photosynthesis, respiration and photorespiration respectively. Unstressed plants maintain the ion homeostasis between production and quenching of these oxidants by raising the level of both enzymatic (SOD, CAT, and POX) and non-enzymatic (proline) antioxidant defense systems in order to overcome the stress [73]. Deleterious effects of salinity increased production of reactive oxygen species which damages membrane, proteins, DNA, RNA and eventually entire plant metabolism is disturbed [74]. It is clear from our results that ROS scavenging enzymes were found in significantly higher accumulation in Pusa-BG5023 compared to Pusa-BGD72 that has less accretion. Therefore, because of less accumulation of antioxidants in Pusa-BGD72, it is more prone to oxidative damages caused due to salt stress. Similar results were reported earlier by [75] in various crop plants. SOD is the first critical enzyme in alleviating the oxidative damage as it rapidly detoxify and transform superoxide radicals to $\mathrm{H}_{2} \mathrm{O}_{2}$ [76]. Hydrogen peroxide is then scavenged by catalase and peroxidase that convert it into $\mathrm{O}_{2}$ and $\mathrm{H}_{2} \mathrm{O}$. Our results are in agreement with the reports of [77] in Morus alba [78], in 
Cicer arietinum [79], in Solanum lycopersicum and [80] in Carthamus tinctorius, who suggested that salinity induces the increased activity of SOD in these plants. Increased concentration of $\mathrm{NaCl}$ also induces the activities of catalase and peroxidase that help to control the redox status by converting $\mathrm{H}_{2} \mathrm{O}_{2}$ into $\mathrm{H}_{2} \mathrm{O}$ and $\mathrm{O}_{2}$ [81,82]. also reported that salinity increases the activity of catalase in several plant species. Costa et al. [83] advocated a strong correlation between salt tolerance and POX activity in sorghum genotypes.

Proline is also involved in the scavenging of free radicals in plants. It is a common and multifunctional osmolyte present in plants and is considered as primary level of defense in plants under stressful conditions. It is a multifunctional amino acid. Under salt stress proline regulates the expression of various genes that are related to enzymatic antioxidants [84]. In present study, proline accumulation increased with increasing concentration of $\mathrm{NaCl}$ treatment, however Pusa-BG5023 accumulated higher amount of proline than Pusa-BGD72 indicating its tolerance towards salinity. The reason behind it is that under stressed conditions, endogenous level of proline increases which decreases the osmotic potential. It ultimately increases water absorption capacity and maintains the turgor pressure up to some limit thus provides the tolerance to plant. Similar results were shown in chickpea under salt stress $[29,85]$.

\section{Conclusion}

Salt stress is a major global problem responsible for the suppression of crop productivity. Chickpea is highly sensitive to salinity, like many other crops. Therefore, identification of salt tolerant variety and salt sensitive variety will be of great practical importance. Present investigation reveals that growth, physiological and biochemical parameters of both the varieties, i.e., Pusa-BG5023 and PusaBGD72 treated with different doses $(50,100,150$ and $200 \mathrm{mM})$ of salt were suppressed. However, PusaBG5023 was emerged to be the more tolerant as compared to Pusa-BGD72 and was least affected in terms of growth, biomass, chlorophyll, carotenoid as well as protein contents. It showed high level of enzymatic antioxidants and accumulation of proline, less malondialdehyde content and enzymatic activity of carbonic anhydrase and nitrate reductase was least affected than other variety, thus proved its highest tolerance towards salinity. Pusa-BGD72 was found to be most sensitive to salt stress due to its maximum reduction in growth, biomass, chlorophyll, carotenoid and protein contents. The membrane damage was also high due to high production of malondialdehyde content. It also showed minimum increase of enzymatic antioxidants, less accumulation of proline, low viability of root cells, altered stomatal behavior and enzymatic activity of carbonic anhydrase and nitrate reductase were highly affected, thus proved its highest sensitivity towards salinity. Hence, we conclude that above studied parameters are helpful in predicting the salt tolerance of chickpea varieties that find support by the data of microscopic studies.

Acknowledgement: The first author is highly grateful to Chairman, Department of Botany, Aligarh Muslim University, India for making available the required facilities and assistance to carry on the experimental work. The author is highly thankful to University Grants Commission for providing UGC Non NET Fellowship.

Ethical Approval: This article did not involve any experiment or study with human participants or animals.

Funding Statement: The authors received no specific funding for this study.

Conflicts of Interest: The authors declare that they have no conflicts of interest to report regarding the present study.

\section{References}

1. Giri, B., Kapoor, R., Mukerji, K. G. (2007). Improved tolerance of acacia nilotica to salt stress by arbuscular mycorrhiza, glomus fasciculatum, may be partly related to elevated $\mathrm{K}^{+} / \mathrm{Na}^{+}$ratios in root and shoot tissues. Microbial Ecology, 54(4), 753-760. DOI 10.1007/s00248-007-9239-9. 
2. Shrivastava, P., Kumar, R. (2015). Soil salinity: A serious environmental issue and plant growth promoting bacteria as one of the tools for its alleviation. Saudi Journal of Biological Science, 22(2), 123-131. DOI 10.1016/j.sjbs.2014.12.001.

3. Rady, M. O., Semida, W. M., El-Mageed, T. A. A., Hemida, K. A., Rady, M. M. (2018). Up-regulation of antioxidative defense systems by glycine betaine foliar application in onion plants confer tolerance to salinity stress. Scientia Horticulturae, 240, 614-622. DOI 10.1016/j.scienta.2018.06.069.

4. Mekuria, W., Aynekulu, E. (2013). Exclosure land management for restoration of the soils in degraded communal grazing lands in northern Ethiopia. Land Degradation \& Development, 24(6), 528-538. DOI 10.1002/ldr.1146.

5. Hu, G., Liu, H., Yin, Y., Song, Z. (2016). The role of legumes in plants community succession of degraded grasslands in northern China. Land Degradation \& Development, 27(2), 366-372. DOI 10.1002/ldr.2382.

6. Javed, Q., Azeem, A., Sun, J., Ullah, I., Jabran, K. et al. (2019). Impacts of salt stress on the physiology of plants and opportunity to rewater the stressed plants with diluted water: A review. Applied Ecology and Environmental Research, 17(5), 12583-12604. DOI 10.15666/aeer.

7. Food and Agriculture Organization of the United Nations (2005). Global Network on Integrated Soil Management for Sustainable Use of Salt-Affected Soils. Rome: FAO Land and Plant Nutrition Management Service.

8. Islam, S., Zaid, A., Mohammad, F. (2020). Role of triacontanol in counteracting the ill efects of salinity in plants: A review. Journal of Plant Growth and Regulators, 40(1), 1-10. DOI 10.1007/s00344-020-10064-w.

9. Lazof, D. B., Bernstein, N. (1999). The $\mathrm{NaCl}$ induced inhibition of shoot growth: The case for disturbed nutrition with special consideration of calcium. In: Callow, J. A. (Ed.), Advances in botanical research incorporating advances in plant pathology, vol. 29, pp. 113-189. Birmingham, University of Birmingham.

10. Foyer, C. H., Noctor, G. (2009). Redox regulation in photosynthetic organisms: Signaling, acclimation, and practical implications. Antioxidant Redox Signaling, 11(4), 861-905. DOI 10.1089/ars.2008.2177.

11. Anjum, N. A., Sofo, A., Scopam, A., Roychoudhury, A., Gill, S. S. et al. (2014). Lipids and proteins-major targets of oxidative modifications in abiotic stressed plants. Environmental Science and Pollution Research, 22(6), 4099-4121. DOI 10.1007/s11356-014-3917-1.

12. Aref, I. M., Khan, P. R., Khan, S., El-Atta, H., Ahmed, A. (2016). Modulation of antioxidant enzymes in Juniperus procera needles in relation to habitat environment and dieback incidence. Trees Structure and Function, 30(5), 1669-1681. DOI 10.1007/s00468-016-1399-0.

13. Ali, B., Hayat, S., Fariduddin, Q., Ahmad, A. (2008). 24 epibrassinolide protects against the stress generated by salinity and nickel in Brassica juncea. Chemosphere, 72(9), 1387-1392. DOI 10.1016/j.chemosphere.2008.04.012.

14. Soussi, M., Ocana, A., Lluch, C. (1998). Effects of salt stress on growth, photosynthesis and nitrogen fixation in chickpea (Cicer arietinum L.). Journal of Experimental Botany, 49(325), 1329-1337. DOI 10.1093/jxb/49.325.1329.

15. Shabala, S. (2009). Salinity and programmed cell death: Unraveling mechanisms for ion specific signalling. Journal of Experimental Botany, 60(3), 709-712. DOI 10.1093/jxb/erp013.

16. Demidchik, V., Cuin, T. A., Svistunenko, D., Smith, S. J., Miller, A. J. et al. (2010). Arabidopsis root K ${ }^{+}$efflux conductance activated by hydroxyl radicals: Single-channel properties, genetic basis and involvement in stressinduced cell death. Journal of Cell Science, 123(9), 1468-1479. DOI 10.1242/jcs.064352.

17. Abreu, I. A., Farinha, A. P., Negrão, S., Gonçalves, N., Fonseca, C. et al. (2013). Coping with abiotic stress: Proteome changes for crop improvement. Journal Proteomics, 93, 145-168. DOI 10.1016/j.jprot.2013.07.014.

18. Deinlein, U., Stephan, A. B., Horie, T., Luo, W., Xu, G. et al. (2014). Plant salt-tolerance mechanisms. Trends in Plant Science, 19(6), 371-379. DOI 10.1016/j.tplants.2014.02.001.

19. Schiop, S. T., Al-Hassan, M., Sestras, A. F., Boscaiu, M., Sestras, R. E. et al. (2015). Identification of salt stress biomarkers in Romanian carpathian populations of Picea abies (L.) karst. PLoS One, 10(8), e0135419. DOI 10.1371/journal.pone.0135419.

20. Bohra, A., Sanadhya, D. (2015). Polyamines: Metabolism and role in abiotic stress amelioration. Journal of Plant Science Research, 31(2), 183-195. DOI 10.3389/fpls.2018.01945.

21. Mushtaq, Z., Faizan, S., Gulzar, B. (2020a). Salt stress, its impacts on plants and the strategies plants are employing against it: A review. Journal of Applied Biology and Biotechnology, 8(3), 81-91. DOI 10.7324/JABB.2020.80315. 
22. Foyer, C. H., Noctor, G. (2011). Ascorbate and glutathione: The heart of the redox hub. Jounal Plant Physiology, 155, 2-18. DOI 10.1104/pp.110.167569.

23. Chawla, S., Jain, S., Jain, V. (2012). Salinity induced oxidative stress and antioxidant system in salt-tolerant and salt-sensitive cultivars of rice (Oryza sativa L.). Journal of Plant Biochemistry and Biotechnology, 22(1), 27-34. DOI 10.1007/s13562-012-0107-4.

24. Munne-Bosch, S. (2005). The role of alpha-tocopherol in plant stress tolerance. Journal of Plant Physiology, 162(7), 743-748. DOI 10.1016/j.jplph.2005.04.022.

25. Rai, G. K., Rai, N. P., Rathaur, S., Kumar, S., Singh, M. (2013). Expression of $r d 29 A: \because A t D R E B 1 A / C B F 3$ in tomato alleviates drought-induced oxidative stress by regulating key enzymatic and non-enzymatic antioxidants. Plant Physiology and Biochemistry, 69, 90-100. DOI 10.1016/j.plaphy.2013.05.002.

26. Gupta, B., Huang, B. (2014). Mechanism of salinity tolerance in plants: Physiological, biochemical, and molecular characterization. International Journal of Genomics, 2014, 18. DOI 10.1155/2014/701596.

27. Rakhmankulova, Z. F., Shuyskaya, E., Shcherbakov, A. V., Fedyaev, V., Biktimerova, G. Y. et al. (2015). Content of proline and flavonoids in the shoots of halophytes inhabiting the South Urals. Russian Journal of Plant Physiology, 62(1), 71-79. DOI 10.1134/S1021443715010112.

28. Talbi, S., Romero-Puertas, M. C., Hernández, A., Terrón, L., Ferchichi, A. et al. (2015). Drought tolerance in a saharian plant Oudneya africana: Role of antioxidant defences. Environmental Experimental Botany, 111, 114126. DOI 10.1016/j.envexpbot.2014.11.004.

29. Mushtaq, Z., Faizan, S., Gulzar, B., Hakeem, K. R. (2020b). Inoculation of rhizobium alleviates salinity stress through modulation of growth characteristics, physiological and biochemical attributes, stomatal activities and antioxidant defence in Cicer arietinum L. Journal of Plant Growth Regulation. DOI 10.1007/s00344-020-10267-1.

30. Ahmad, P. (2010). Growth and antioxidant responses in mustard (Brassica juncea L.) plants subjected to combined effect of gibberelic acid and salinity. Archives of Agronomy and Soil Science, 56(5), 575-588. DOI 10.1080/ 03650340903164231.

31. Ahmad, P., Hakeem, K. R., Kumar, A., Ashraf, M., Akram, N. A. (2010). Salt-induced changes in photosynthetic activity and oxidative defense system of three cultivars of mustard (Brassica juncea L.). African Journal of Biotechnology, 11(11), 2694-2703. DOI 10.5897/AJB11.3203.

32. Kumar, V., Shriram, V., Kavi Kishor, P. B., Jawali, N., Shitole, M. G. (2010). Enhanced proline accumulation and salt stress tolerance of transgenic indica rice by over-expressing P5CSF129A gene. Plant Biotechnology Reports, 4, 37-48. DOI 10.1007/s11816-009-0118-3.

33. Ashraf, M., Harris, P. J. C. (2004). Potential biochemical indicators of salinity tolerance in plants. Plant Science, 166, 3-16. DOI 10.1016/j.plantsci.2003.10.024.

34. Hokmabadi, H., Arzani, K., Grierson, P. F. (2005). Growth, chemical composition, and carbon isotope discrimination of pistachio (Pistacia vera L.) rootstock seedlings in response to salinity. Australian Journal of Agricultural Research, 56, 135-144. DOI 10.1071/AR04088.

35. Varshney, R. K., Hiremath, P. J., Lekha, P., Kashiwagi, J., Balaji, J. et al. (2009). A comprehensive resource of drought-and salinity-responsive ESTs for gene discovery and marker development in chickpea (Cicer arietinum L.). Bio Medical Central Genomics, 10, 523-541. DOI 10.1186/1471-2164-10-523.

36. Flowers, T. J., Gaur, P. M., Gowda, C. L. L., Krishnamurthy, L., Samineni, S. et al. (2010). Salt sensitivity in chickpea. Plant Cell Environment, 33(4), 490-509. DOI 10.1111/j.1365-3040.2009.02051.x.

37. Lichtenthaler, H., Buschmann, B. (2001). Chlorophylls and carotenoids: Measurement and characterization by UV-VIS spectroscopy. Current Protocols in Food Analytical Chemistry, 1, F4.3.1-F4.3.8. DOI 10.1002/ 0471142913.faf0403s01.

38. Cakmak, I., Horst, J. H. (1991). Effects of aluminum on lipid peroxidation, superoxide dismutase, catalase, and peroxidase activities in root tips of soybean (Glycine max). Physiologia Plantarum, 83(3), 463-468. DOI 10.1111/j.1399-3054.1991.tb00121.x.

39. Jaworski, E. G. (1971). Nitrate reductase assay in intact plant tissues. Biochemical and Biophysical Research Communications, 43(6), 1274-1279. DOI 10.1016/s0006-291x(71)80010-4. 
40. Dwivedi, R. S., Randhawav, N. S. (1974). Evaluation of rapid test for the hidden hunger of zinc in plants. Plant Soil, 40, 445-451. DOI 10.1007/BF00011531.

41. Beauchamp, C., Fridovich, I. (1971). Superoxide dismutase: Improved assays and an assay applicable to acrylamide gels. Analytical Biochemistry, 44(1), 276-287. DOI 10.1016/0003-2697(71)90370-8..

42. Bates, L., Waldren, R., Teare, I. (1973). Rapid determination of free proline for water-stress studies. Plant Soil, 39(1), 205-207. DOI 10.1007/BF00018060.

43. Sanchez, M., Revilla, G., Zarra, I. (1995). Changes in peroxidase activity associated with cell walls during pine hypocotyl growth. Annals of Botany, 75(4), 415-419. DOI 10.1006/anbo.1995.1039.

44. Aebi, H. (1984). Catalase in vitro. Methods in Enzymology, 105(84), 121-126. DOI 10.1016/s0076-6879(84) 05016-3.

45. Bradford, M. M. (1976). A rapid sensitive method for the quantification of microgram quantities of protein utilizing the principle of protein-dye binding. Analytical Biochemistry, 72(7), 248-254. DOI 10.1006/ abio.1976.9999.

46. Kaur, N., Sharma, I., Kirat, K., Pati, P. K. (2016). Detection of reactive oxygen species in Oryza sativa L. (Rice). Bio-Protocol, 6(24), 1-9. DOI 10.21769/BioProtoc. 2061.

47. Shabala, S., Bose, J., Hedrich, R. (2014). Salt bladders: Do they matter? Trends in Plant Science, 19, 687-691. DOI 10.1016/j.tplants.2014.09.001.

48. Parida, A. K., Das, A. B. (2005). Salt tolerance and salinity effects on plants: A review. Ecotoxicology and Environmental Safety, 60(3), 324-349. DOI 10.1016/j.ecoenv.2004.06.010.

49. Gunes, A., Inal, A., Alpaslan, M. (1996). Effect of salinity on stomatal resistance, proline and mineral composition of pepper. Journal of Plant Nutrition, 19(2), 389-396. DOI 10.1080/01904169609365129.

50. Çavusoglu, K., Kabar, K. (2010). Effects of hydrogen peroxide on the germination and early seedling growth of barley under $\mathrm{naCl}$ and high temperature stresses. Eurasian Journal of Bioscience, 4(1), 70-79. DOI 10.5053/ ejobios.2010.4.0.9.

51. Duan, L., Sebastian, J., Dinneny, J. R. (2015). Salt-stress regulation of root system growth and architecture in arabidopsis seedlings. Methods of Molecular Biology, 1242, 105-122. DOI 10.1007/978-1-4939-1902-4_10.

52. Jamil, M., Rha, E. S. (2004). The effect of salinity (NaCI) on the gemilnation and seedling of sugar beet (Beta vulgaris L.) and cabbage (Brassica oleracea L.). Korean Journal of Plant Resources, 7(3), 226-232.

53. Mathur, N., Singh, J., Bohra, S., Bohra, A., Vyas, A. (2006). Biomass production, productivity and physiological changes in moth bean genotypes at different salinity levels. American Journal of Plant Physiology, 1(2), 210-213. DOI 10.3923/ajpp.2006.210.213.

54. Jamil, M., Rehman, S., Rha, E. S. (2007). Salinity effect on plant growth, PSII photochemistry and chlorophyll content in sugar beet (Beta vulgaris L.) and cabbage (Brassica oleracea capitata L.). Pakistan Journal of Botany, 39(3), 753-760.

55. Taffouo, V. D., Wamba, O. F., Youmbi, E., Nono, G. V., Akoa, A. (2010). Growth, yield, water status and ionic distribution response of three bambara groundnut (Vigna subterranea L. Verdc.) landraces grown under saline conditions. International Journal of Botany, 6(1), 53-58. DOI 10.3923/ijb.2010.53.58.

56. Puvanitha, S., Mahendran, S. (2017). Effect of salinity on plant height, shoot and root dry weight of selected rice rultivarses. Scholars Journal of Agriculture and Veterinary Sciences, 4(4), 126-131. DOI 10.21276/sjavs.

57. Siddiqui, M. H., Alamri, S., Al-Khaishany, M. Y., Khan, M. N., Al-Amri, A. et al. (2019). Exogenous melatonin counteracts naCl-induced damage by regulating the antioxidant system, proline and carbohydrates metabolism in tomato seedlings. International Journal of Molecular Sciences, 20(2), 353. DOI 10.3390/ijms20020353.

58. Abd-Allaa, M. H., Nafadya, N. A., Shymaa, R., Bashandya, S. R., Hassan, A. A. (2019). Mitigation of effect of salt stress on the nodulation, nitrogen fixation and growth of chickpea (Cicer arietinum L.) by triple microbial inoculation. Rhizosphere, 10(5), 1-11. DOI 10.1016/j.rhisph.2019.100148.

59. Munns, R., James, R. A. (2003). Screening methods for salt tolerance: A case study with tetraploid wheat. Plant Soil, 253, 201-218. DOI 10.1023/A:1024553303144. 
60. Kusvuran, S., Eilialtioglu, S., Abalc, K., Yasar, F. (2007). Some melon genotypes to salt stress reaction. Ankara University Journal of Agricultural Science, 13(4), 395-404.

61. Yousuf, P. Y., Ahmad, A., Ganie, A. H., Sareer, O., Krishnapriya, V. et al. (2016). Antioxidant response and proteomic modulations in Indian mustard grown under salt stress. Plant Growth Regulation, 81(1), 31-50. DOI 10.1007/s10725-016-0182-y.

62. Hayat, S., Yadav, S., Wani, A. S., Irfan, M., Ahmad, A. (2011). Screening of salt-tolerant genotypes of Brassica juncea based on photosynthetic attributes. Journal of Plant Interactions, 6(1), 53-60. DOI 10.1080/ 17429145.2010.521592.

63. Abdul Qados, A. M. S. (2011). Efect of salt stress on plant growth and metabolism of bean plant Vicia faba (L.). Journal of the Saudi Society of Agricultural Sciences, 10(1), 7-15. DOI 10.1016/j.jssas.2010.06.002.

64. Taibi, K., Taibi, F., Abderrahim, L. A., Ennajah, A., Belkhodja, M. et al. (2016). Effect of salt stress on growth, chlorophyll content, lipid peroxidation and antioxidant defense systems in Phaseolus vulgaris L. South Aferican Journal of Botany, 105, 306-312. DOI 10.1016/j.sajb.2016.03.011.

65. Demiral, T., Turkan, I. (2006). Exogenous glycine betaine affects growth and proline accumulation and retards senescence in two rice cultivars under naCl stress. Environmental and Experimental Botany, 56(1), 72-79. DOI 10.1016/j.envexpbot.2005.01.005.

66. Kumari, R. P., Vishnuvardhan, Z. (2015). Effect of salinity on growth, protein and antioxidant enzymes in three kodo millet (Paspalum scrobiculatum) germplasm. International Journal of Current Microbiology and Applied Science, 4(6), 475-483.

67. Ahmad, P., Jaleel, C. A., Sharma, S. (2012). Antioxidative defense system, lipid peroxidation, proline metabolizing enzymes and biochemical activity in two genotypes of Morus alba L. subjected to $\mathrm{NaCl}$ stress. Russian Journal of Plant Physiology, 57(4), 509-517. DOI 10.1134/S1021443710040084.

68. Sharma, P., Jha, A. B., Dubey, R. S., Pessarakli, M. (2012). Reactive oxygen species, oxidative damage, and antioxidative defense mechanism in plants under stressful conditions. Journal of Botany, 2012, 1-26. DOI $10.1155 / 2012 / 217037$.

69. Demiral, T., Turkan, I. (2005). Comparative lipid peroxidation, antioxidant defense systems and proline content in roots of two rice cultivars differing in salt tolerance. Environmental and Experimental Botany, 53(3), 247-257. DOI 10.1016/j.envexpbot.2004.03.017.

70. Maudhania, S., Madan, S., Sawimey, V. (2006). Antioxidant defense mechanism under salt stress in wheat seedlings. Biologia Plantarum, 227, 227-231. DOI 10.1007/s10535-006-0011-7.

71. Campbell, H. W. (1999). Nitrate reductase structure, function and regulation bridging the gap between biochemistry and physiology. Annual Review of Plant Physiology and Plant Molecular Biology, 50(1), 277303. DOI 10.1146/annurev.arplant.50.1.277.

72. Sharma, P., Jha, A. B., Dubey, R. S. (2010). Oxidative stress and antioxidative defence system in plants growing under abiotic stresses. In: Pessaraki, M. (Ed.), Handbook of plant and crop stress, pp. 89-138. Third edition. Florida, USA: CRC Press.

73. Gill, S. S., Tuteja, N. (2010). Reactive oxygen species and antioxidant machinery in abiotic stress tolerance in crop plants. Plant Physiology and Biochemistry, 48(12), 909-930. DOI 10.1016/j.plaphy.2010.08.016.

74. del-Rio, L. A. (2015). ROS and RNS in plant physiology: An overview. Journal of Experimental Botany, 66(10), 2827-2837. DOI 10.1093/jxb/erv099.

75. Siddiqi, E. H. (2010). Influence of salt stress on some physiological and biochemical attributes and oil composition of a potential oilseed crop safflower (Carthamus tinctorius L.) (Ph.D. Thesis). Department of Botany, University of Agriculture, Faisalabad.

76. Nabati, J., Kafi, M., Nezami, A., Moghaddam, P. R., Masomi, A. et al. (2011). Effect of salinity on biomass production and activities of some key enzymatic antioxidents in kochia (Kochia scoparia). Pakistan Journal of Botany, 43(1), 539-548.

77. Harinasut, P., Poonsopa, D., Roengmongkol, K. (2003). Salinity effects on antioxidant enzymes in mulberry cultivar. Science Asia, 29(2), 109-113. DOI 10.2306/scienceasia1513-1874.2003.29.109. 
78. Kukreja, S., Nandwal, A. S., Kumar, N., Sharma, S. K., Sharma, S. K. et al. (2005). Plant water status, $\mathrm{H}_{2} \mathrm{O}_{2}$ scavenging enzymes, ethylene evolution and membrane integrity of cicer arietinum roots as affected by salinity. Biologia Plantarum, 49(2), 305-308. DOI 10.1007/s10535-005-5308-4.

79. Gapinska, M., Skodowska, M., Gabara, B. (2008). Effect of short-and long-term salinity on the activities of antioxidative enzymes and lipid peroxidation in tomato roots. Acta Physiologia Plantarium, 30, 11-18. DOI 10.1007/s11738-007-0072-z.

80. Gengmao, Z., Yu, Z., Xing, S. (2015). Salinity stress increases secondary metabolites and enzyme activity in safflower. Industrial Crops and Products, 64(1), 175-181. DOI 10.1016/j.indcrop.2014.10.058.

81. Eyidogan, F., Oz, M. T. (2005). Effect of salinity on antioxidant responses of chickpea seedlings. Acta Physiologia Plantarum, 29(5), 485-493. DOI 10.1007/s11738-007-0059-9.

82. Yang, Y., Han, C., Liu, Q., Lin, B., Wang, J. (2008). Effect of drought and low light on growth and enzymatic antioxidant system of Picea asperata seedlings. Acta Physiologia Plantarum, 30, 433-440. DOI 10.1007/ s11738-008-0140-z.

83. Costa, P. H. A., Neto, A. D. A., Bezerra, M. A., Frisco, J. T., Gomes-Filho, E. (2005). Antioxidant enzymatic system of two sorghum genotypes differing in salt tolerance. Brazilian Journal of Plant Physiology, 17(4), 353-361. DOI 10.1590/S1677-04202005000400003.

84. Kim, G. B., Nam, Y. W. (2013). A novel $\Delta^{1}$-pyrroline-5-carboxylate synthetase gene of Medicago truncatula plays a predominant role in stress-induced proline accumulation during symbiotic nitrogen fixation. Journal of Plant Physiology, 170(3), 291-302. DOI 10.1016/j.jplph.2012.10.004.

85. Rasool, S., Ahmad, A., Siddiqi, T. O., Ahmad, P. (2013). Changes in growth, lipid peroxidation and some key antioxidant enzymes in chickpea genotypes under salt stress. Acta Physiologia Plantarum, 35, 1039-1050. DOI 10.1007/s11738-012-1142-4. 